\title{
STUDENTS' PERCEPTION TOWARDS THE IMPLEMENTATION OF TALKING STICK MODEL TO PRACTICE ENGLISH SPEAKING SKILL
}

\author{
$1^{\text {st }}$ Syahyuri \\ English Education Department \\ Universitas Indraprasta PGRI \\ Jakarta, Indonesia \\ yuri.syahyuri@gmail.com
}

\author{
$2^{\text {nd }}$ Riyanto \\ English Education Department \\ Universitas Indraprasta PGRI \\ Jakarta, Indonesia \\ riyanto@gmail.com
}

\begin{abstract}
This research aimed to find out the students' perception on the implementation of Talking Stick model to practice speaking skill, whether it is positive or negative. Since English is considered as a foreign language in Indonesia, so it is very important to practice the students' speaking skill to communicate effectively. The English teacher however, can use the learning model as the classroom activity to motivate and engage the students to be confident to speak in front of the class. There many learning model, one of them is Talking Stick model. This learning model gives more opportunity to the students to speak in front of the class by using Talking Stick. The researcher formulated two questions. The researcher employed a survey model. There are two research instruments in this research which are questionnaire and interview.
\end{abstract}

Keywords: perception, talking stick, speaking skill.

\section{INTRODUCTION}

People use language in their daily lives to interact each other. Language is very important thing in doing communication. Through communication, human can convey the ideas, express their opinions, and it can even develop the other sciences that they have. A language has not only a structure but also a function to which that structure is put. We use language as a media of communication with other people, or it can be like a tool to express our ideas and wishes. Without language, it is hard to imagine how people can cooperate and get along with one another. So, communication has an important role in human life. We must know how to share, to express our idea to other.

Since communication is important, human being should learn how to communicate correctly. Communication will be easy if between sender and receiver understands with the information given. One of important tools in communication among various groups of people from various part of the world now is language, and the most use language internationally is English.
There are four skills in the language, namely: listening, speaking, reading and writing. From those four langaue skills, speaking is being focused in this research. Nunan (2003:48) states that speaking is the productive aural/oral skill. It consists of producing systematic verbal utterances to convey meaning. When someone speaks, he or she interacts and uses the language to express his or her ideas, feeling, and thought. $\mathrm{He}$ or she also shares information to others through communication.

Speaking is an important part of everyday interaction and most often the first impression of a person based on his/her ability to speak fluently and comprehensibly. So, teacher has a responsibility to prepare the students as much as possible to be able to speak English in the real situation outside the classroom. Thus, being an English teacher speaking needs a big effort to be an attractive English teacher and to motivate the students to participate in the speaking activities.

The effort of being an attractive English teacher has been done by one of STKIP Panca Sakti students who did the teaching practice 
$(P P L)$ at SMK TEKNIKOM Sukatani-Bekasi academic year 2018/2019. He implemented the Talking Stick as the model to practice English speaking during the teaching and learning process. The students at SMK TEKNIKOM especially grade eleven seem anxiety anytime they speak English. They understand if someone speaks English but they are not courageous enough to respond it. There are several factors that become the difficulties in speaking, such as poor pronunciation, intonation of their expressions, and less vocabulary mastery.

Hogan (2007) stated that the traditional Talking Stick has been used for centuries by many American Indian tribes as a means of just and impartial hearing. The Talking Stick was commonly used in council circles to designate who had the right to speak. It means that a Talking Stick is given to the students to make the students be motivated to speak. Talking Stick is one of models to solve problems in speaking. Talking Stick model can help students to feel happy, enjoy and interest. As the result, teacher is easier to manage the students in the learning process. The other advantages of Talking Stick model is that the students become more active in doing activities such as; answering teacher's questions and speaking. So, they do not feel bored in their study. Finally, they could improve their confidence.

Based on the explanation above the researcher is eager to know whether the students' perception is positive or negative towards the implementation of Talking Stick. Moreover, the students' perception on the implementation of the Talking Stick model can be an important asset for teachers to practice students speaking skills in the classroom.

\section{METHOD}

In this research, the researcher employs survey research to collect the data. The researcher chose this model because the research focused on the students' perception on the implementation of the Talking Stick model and their suggestions for further implementation of the Talking Stick model. According to Wiersma (1995: 169), "survey is used to measures attitudes, opinions, or achievements, any number of variables in natural setting". Moreover, Creswell (2005: 385 ), states that survey researchers typically collect data using two basic forms: questionnaires and interviews". Therefore, to answer two research questions in the formulation of the research used questionnaires and interviews as the research instruments.

The population of this study is all of students in eleventh grade at SMK TEKNIKOM Sukatani-Bekasi in the academic year 2018/2019 which amounts about to 356 students. Frankel and Norman (2012: 92) stated that population is the larger group to which one hopes to apply the results. The researcher then chose sample random sampling as the technique to determine the sample. The number of sample is 36 students.

The data used numerical form in percentage. The formula of calculation is shown as follow:

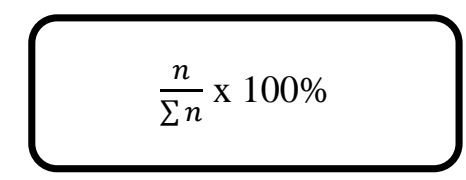

n : Number of the students that choose certain option.

$\sum n \quad:$ Total Students

\section{RESULT AND DISCUSSION}

Students of class subjects STKIP especially microeconomic theory, the Indonesian economy, and an introductory economics class $\mathrm{A}$ and $\mathrm{B}$. They prefer learning model that is guided by the lecturer then lecturer gives examples of problems and their discussions to find a solution.

There were eight statements from the result of the questionnaire that is detailed in as below:

The percentage of the Questionnaire Result: 


\begin{tabular}{|c|c|c|c|c|c|}
\hline 1 & $\begin{array}{l}\text { I feel confident when the first } \\
\text { time doing the Talking Stick } \\
\text { model in the learning process. }\end{array}$ & $2,7 \%$ & $14 \%$ & $83 \%$ & $0 \%$ \\
\hline 2 & $\begin{array}{l}\text { The learning process with the } \\
\text { Talking Stick model makes me } \\
\text { understand the material faster. }\end{array}$ & $5,6 \%$ & $81 \%$ & $14 \%$ & $0 \%$ \\
\hline 4 & $\begin{array}{l}\text { The learning process with the } \\
\text { Talking Stick helps me study } \\
\text { hard. }\end{array}$ & $5,6 \%$ & $75 \%$ & $30,5 \%$ & $0 \%$ \\
\hline 4 & $\begin{array}{l}\text { The learning process with the } \\
\text { Talking Stick is testing my } \\
\text { readiness to understand the } \\
\text { materials. }\end{array}$ & $5,6 \%$ & $61 \%$ & $19,4 \%$ & $11 \%$ \\
\hline 5 & $\begin{array}{l}\text { The learning process with the } \\
\text { Talking Stick gives me an } \\
\text { opportunity to speak in English }\end{array}$ & $8,3 \%$ & $75 \%$ & $17 \%$ & $0 \%$ \\
\hline 6 & $\begin{array}{l}\text { The learning process with the } \\
\text { Talking Stick helps me to } \\
\text { improve my speaking skill in } \\
\text { English. }\end{array}$ & $8,3 \%$ & $78 \%$ & $11 \%$ & $0 \%$ \\
\hline 7 & $\begin{array}{l}\text { The learning process with the } \\
\text { Talking Stick encourages me to } \\
\text { speak in English fluently. }\end{array}$ & $11 \%$ & $78 \%$ & $11 \%$ & $0 \%$ \\
\hline 8 & $\begin{array}{l}\text { The learning process with the } \\
\text { Talking Stick model is suitable } \\
\text { to be implemented in the } \\
\text { classroom, especially to practice } \\
\text { speaking skill. }\end{array}$ & $14 \%$ & $75 \%$ & $11 \%$ & $2,7 \%$ \\
\hline & Average Percentage & $7,7 \%$ & $67 \%$ & $25 \%$ & $1,7 \%$ \\
\hline
\end{tabular}

This part consists of two sections, they are: the students" perception on the implementation of Talking Stick model and the students' suggestions for further implementation of the Talking Stick model.

\section{The Students' Perception on the implementation of the Talking Stick Model.}

Based on the average percentage of the questionnaire, there are 7,7\% of the students strongly agree, $67 \%$ of the students agree, $25 \%$ disagree, and 1, 7\% strongly disagree. The result shows that the students give positive perception on the Talking Stick model. It is proved by the average percentage of strongly agree and agree are bigger number than disagree and strongly disagree.

\section{The students' suggestions for further implementation of the Talking Stick Model}

Based on the result of the interview, the students shared some suggestions for further implementation of Talking Stick model. Of course Talking Stick model has advantages and disadvantages but the students were happy using Talking Stick model during the teaching and learning process especially to practice speaking skills. simply, the students suggestion were beneficial to develope further implemtation of the Talking Stick model. The students were happy and succesfull using Talking Stick model. It is recommended for teachers to use Talking Stick model to practice English in order to improve students' speaking skill.

\section{CONCLUSION}

The conclusion deal with the research result based on the two research questions in this research. The first research question is about the students' perception on the implementation of the Talking Stick model to practice speaking skill at SMK TEKNIKOM Sukatani-Bekasi. Based on the results of the questionnaires and interviews, the researcher concluded that the students gave positive perception on the implementation of Talking Stick model. Then, the students perceived that The Talking Stick model was really nice, attractive, and easy to be implemented. The students thought that this learning model is very useful to practice English speaking during the teaching and learning process in the classroom.

The second research question is about the students' suggestions towards further implementation of the Talking Stick model. So far the students said that they enjoyed the learning process using Talking Stick model, they suggested having more various shapes of the stick.

\section{REFERENCES}

Creswell, J. W. (2003). Research Design Qualitative, Quantitative and Mixed Methods Approaches Second Edition. New Delhi: Sage Publications

Fraenkel, Jack. R., and Norman E. W. (2012). How to Design and Evaluate Research in Education 8th Edition. Boston: McGraw-Hill Higher Education.

Hogan, C. (2007). Facilitating Multicultural Groups: A Practical Guide. Philadelphia: Kogan Page.

Nunan, D. (1991). Language Teaching Methodology: A Textbook for 
Teacher. Upper Saddle River, NJ:

Prentice Hall.

Shoimin, A. (2016). 68 Model Pembelajaran Inovatif dalam Kurikulum 2013. Yogyakarta: Ar-Ruzz Media.

Wersma, W (1995). Research Methods in Educational Introduction. Boston: Allyn and Bacon. 